\title{
BIBLIOGRAFIA PRAC PUBLIKOWANYCH KS. PROF. DRA HAB. STANISŁAWA GRZYBKA
}

\author{
(część III: 1996-1998)
}

[cześć I (1948-1980) została opublikowana w RBL 5(1980) 291-297; cz. II (1981-1995) RBL 1(1996) 63-67]

1996

1. Biblia na co dzień, t. II Wielki Post - Wielkanoc (współautor z ks. A. Troniną). W-wa 1996, 7-56;

2. Wielbi dusza moja Pana. Częstochowa 1996, 59;

3. Homilie niedzielne. Nasze Słowo. Dwutygodnik Katolickiej Misji Polskiej w Niemczech. 18(1996) 4/5; 19(1996) 4.5; 20(1996) 4; 27(1996) 4.5;

4. rec. Łach J., Z myślą o rodzinie. Komentarz biblijno-ascetyczny do czytań ślubnych. Tarnów 1995; RBL 1(1996) 67-68;

5. rec. Grudniok Fr., Która wiele umiłowała. Wrocław 1995; RBL 2(1996)141-142; Homo Dei 1(1996) 88-90;

6. rec. Ewangelia według św. Mateusza z komentarzem ks. T. Loski. Katowice 1995; RBL 3(1996) 214-216;

\section{7}

7. Wielbi dusza moja Pana (Łk 1,46). Analiza historycznoteologiczna hymnu Magnifikat. Sosnowieckie Studia Teologiczne, t. III, 1997, 231-251;

8. Homilie niedzielne. Nasze Słowo. Dwutygodnik Katolickiej Misji Polskiej w Niemczech. 2(1997) 4; 4(1997) 5; 175-187;

9. Bóg Izajasza w świetle jego misji (Iz 6,2-13). RBL 3(1997)

10. Teologia kapłańskiego opisu stworzenia świata (1,1-2, 4a). Wiad. Archidiecezji Częstochowskiej 5(1997) 35-45;

11. Wymowa milczących cmentarzy. Niedziela 43A(1997) 3;

12. Zatroskana o najbiedniejszych. Gość Niedzielny 44(1997)13; Wiad. Arch. Częst. 10-11(1997)27-32;

13. rec. Grudniok Fr., Pan idzie z nieba. Bytom 1997; RBL 2(1997)166-167;

14. rec. bp Długosz A., Jak przygotować i ocenić katechezę? Częstochowa 1997; Wiad. Arch. Częst. 10-11(1997) 45-47;

15. rec. Ponizy B., Korzenie przesłania biblijnego Nowego Testamentu. Poznań 1997; RBL 4(1997) 309; 
16. rec. Dziuba A.Fr., Matka Boża z Guadelupe. Katowice 1995; RBL 3(1997) 230-232;

17. Usłyszeliśmy w Radio Maryja. Omówienie publikacji bpa A. Małysiaka „Duszpasterstwo Społeczne”. Pogadanki w Radio Maryja. Niedziela 38A(1997) 20;

1998

18. rec. Grudniok Fr., Z dnia na dzień. Rozważania. Wrocław 1998; RBL 3(1998) 245-246;

19. rec. bp Długosz A., Jak przygotować i ocenić katechezę. Częstochowa 1997; Homo Dei 1(1998) 139-141;

20. Ludzkie drogi naszego życia w kontekście Psalmu 1. RBL 1(1997)1-7.

21. Służba jako element konstytutywny apostolstwa świeckich. Sosnowieckie Studia Teologiczne, t. V, 1999, 105-113.

UZUPEŁNIENIE do poprzednio opublikowanej bibliografii:

1. Manuskrypty z Qumran a chrześcijaństwo. Tyg. Powszechny 14(1960) 3.6;

2. Księga Estery - Wstęp, przekład i komentarz. w: Pismo Święte Starego Testamentu. Poznań 1963, 178;

3. rec. Bea A., La parola di Dio e l'umanità. Assisi 1967; Ateneum Kapłańskie, t.73, 3(1969) 470-473;

4. Biblijna teologia męczeństwa. Gość Niedzielny 31(1982)4-5.

Kraków

zestawił KS. TADEUSZ MATRAS

\section{Józef Marecki OFMCap. \\ ŚP. O. ZDZISŁAW RZESZUTEK OFMCAP (1918-1998)}

W dniu 12 września 1998 roku w krakowskim klasztorze kapucynów, po krótkiej ale ciężkiej chorobie, odszedł do Pana po wieczną nagrodę o. Zdzisław Jan Bolesław Rzeszutek.

Urodził się w dniu 26 maja 1918 roku w Majdanie Królewskim (woj. rzeszowski) w rodzinie Jana i Katarzyny z Jagodów. Początkowo uczył się w miejscowej szkole powszechnej, a w latach 1929-1932 w Kolegium Serafickim OO. Kapucynów w Rozwadowie (obecnie Stalowa Wola). Do Zakonu OO. Kapucynów wstąpił w dniu 29 sierpnia 1933 roku w Sędziszowie Młp. Rok później, po ukończeniu nowicjatu, złożył śluby proste, zaś dnia 28 maja 1939 roku w klasztorze kapucynów w Krakowie śluby uroczyste. Gimnazjum oraz filozofię i teologię 